\title{
ANÁLISE DO JOGO LIFE IS STRANGE E SUAS POTENCIALIDADES DE INTERAÇÃO COM O SUJEITO-LEITOR/ JOGADOR
}

\author{
ANALYSIS OF THE GAME LIFE IS STRANGE AND ITS \\ POTENTIALS OF INTERACTION WITH THE SUBJECT READER \\ / PLAYER
}

\author{
Isabela Vieira Lima ${ }^{1}$ \\ Helena Maria Ferreira ${ }^{2}$
}

\begin{abstract}
Resumo: Com a popularização dos jogos eletrônicos como produto cultural, novas pesquisas têm encontrado modos diferentes de analisar esse objeto de estudo, atravessando fronteiras em direção às possibilidades pedagógicas. Nesse sentido, pretende-se analisar as potencialidades que o trabalho com jogos digitais pode trazer para o aperfeiçoamento de habilidades relacionadas aos multiletramentos por parte de alunos leitores/jogadores em sala de aula, de acordo com os conceitos discutidos por Ribeiro (2009), Rojo (2012), Xavier (2013), Dionísio (2005, 2011) entre outros. A análise foi realizada utilizando-se capturas de tela do jogo Life is strange (2015), ${ }^{3}$ a fim de observar seus aspectos estruturais, textuais e interacionais. Desse modo, foi possível considerar que os games exigem dos jogadores habilidades específicas para garantir a qualidade das interações, propiciando contribuições substanciais para a formação de leitores, já que ler/jogar demanda saberes diversos sobre o jogo, mas, sobretudo, sobre os usos sociais das diferentes linguagens e de seus efeitos de sentido.
\end{abstract}

Palavras-chave: Multiletramentos. Jogos digitais. Formação do leitor.

\begin{abstract}
With the popularization of electronic games as a cultural product, new research have found different ways of analyzing this object of study, crossing barriers with regards to pedagogic possibilities. In this sense, is intend to analyze the potentialities of working with digital games can bring to the perfecting of skills related to multiliteracies on the part of the reader/player students on a classroom, according to concepts discussed by Ribeiro (2009), Rojo (2012), Xavier (2013), Dionísio (2005, 2011) among others. The analysis will be performed by using screenshots from the game Life is Strange, in order to observe its structural, textual and interactional aspects. From the study, was possible to consider that games require from the players specific skills to ensure quality of interaction, providing substantial contributions to the formation of readers, since read/play demands diverse game knowledge but, mainly, knowledge about the social uses of the different languages and their effects of meaning.
\end{abstract}

Keywords: Multiliteracies. Digital games. Formation of reader.

\section{Introdução}

Os jogos digitais, como qualquer texto, possuem inúmeros níveis de compreensão, e seu estudo, apesar de ainda ser pouco difundido, já sinaliza várias possibilidades pedagógicas. A aprendizagem baseada em jogos digitais é eficaz, pois, segundo Prensky (2012), ela se familiariza com a atual geração de nativos digitais (aqueles que nasceram já cercados pela tecnologia) e utiliza técnicas de aprendizagem interativa, as quais permitem praticar os usos sociais da língua e aprender com eles, por meio do estabelecimento de metas, do cumprimento de tarefas, da realização de descobertas, entre outros pontos que estão relacionados a uma aprendizagem autônoma, em que o aluno tem controle do seu próprio processo de aprendizagem. Além disso, essa

\footnotetext{
${ }^{1}$ Universidade Federal de Lavras. E-mail: isabelavieiralima_@hotmail.com

${ }^{2}$ Universidade Federal de Lavras. E-mail: helenaferreira@ufla.br

3 LIFE IS STRANGE. França: Dontnod Entertainment, 2015. 1 jogo (cinco episódios). Plataforms: PlayStation 4, Xbox One, PlayStation 3, Xbox 360, Microsoft Windows, Mac OS Classic, Linux. Disponível em: http://store.steampowered.com/. Acesso em: 16 nov. 2018.
} 
aprendizagem é motivadora, por permitir a liberdade de experimentar os diversos caminhos propostos, estimulando a capacidade de buscar novas respostas e diferentes soluções para um mesmo desafio.

Em função de tais aspectos e devido ao intenso processo de evolução das tecnologias da informação e comunicação (TIC), bem como sua recorrente participação na vida cotidiana, é possível caracterizar os jogos digitais como objetos de aprendizagem tecnológicos, a fim de ressignificar as práticas sociais de leitura e escrita, gerando, assim, novos tipos de interação incorporados às práticas educativas.

Ademais, além do seu caráter interacional, os jogos digitais se constituem como textos multimodais e, conforme discutido por autores, como Almeida e Valente (2012), Santaella (2003, 2005, 2009), Dionísio (2005, 2011) e Xavier (2013), é preciso que os professores apresentem atividades para desenvolver as habilidades de compreensão desses textos. A proposição de atividades didáticas se justifica em função de a organização multimodal dos textos (imagem, fala e escrita) possibilitar mudanças substanciais na forma de elaborar sentido e significados (DIONÍSIO, 2011). Nesse sentido, por meio desta pesquisa, tem-se como objetivo analisar as potencialidades que o trabalho com narrativas em mídias eletrônicas pode trazer para o aperfeiçoamento de habilidades relacionadas aos multiletramentos por parte de alunos leitores/jogadores, de acordo com os conceitos trazidos por Ribeiro (2009), Dionísio (2005, 2011) e Rojo (2012). Além disso, a investigação proposta será organizada a partir da caracterização do objeto, Life is strange (2015), por meio de estudos relacionados aos campos de pesquisa em jogos digitais, segundo estudos desenvolvidos por Aguiar (2017), Moreira e Cruz (2009) e Silveira e Rolim (2013).

Nesse contexto, o trabalho em pauta está organizado em cinco partes. Inicialmente, é proposta uma reflexão sobre as relações entre tecnologia e a educação. Em seguida, é discutido como essas novas relações existentes têm interferido no desenvolvimento das habilidades dos letramentos pelos sujeitos. Posteriormente, através de pesquisas relacionadas aos games studies e às narrativas digitais, é realizada uma discussão acerca do gênero digital game, para que seja correlacionado às novas possibilidades pedagógicas em sala de aula, em função da sua multidisciplinaridade. Além disso, por fim, os recortes do jogo Life is strange são analisados com base em seus aspectos estruturais, textuais, narrativos, interacionais e de jogabilidade, todos relacionados à dimensão dos multiletramentos desenvolvidos por sujeitos leitores/jogadores. Ao final, é possível considerar as diversas contribuições do trabalho com os jogos digitais em sala de aula.

\section{Tecnologia e educação}

As transformações das práticas sociais em função das tecnologias de informação e comunicação fizeram emergir a chamada cultura digital, ou cibercultura (SANTAELLA, 2003), e têm permitido a convergência de diversos conhecimentos em um mesmo ambiente, afetando, principalmente, a área da educação, pois se há sujeitos que interagem com os textos digitais, há também que se falar do letramento digital e em como os recursos utilizados nesses textos abrem possibilidades de aprendizagem nos currículos escolares.

Diferentemente do que se presenciava em tempos anteriores, a utilização de recursos tecnológicos em sala de aula tem tido mais aceitação, a julgar pela disseminação de pesquisas que evidenciam várias contribuições que derivam dessas novas metodologias, entretanto, o que se discute é o estabelecimento efetivo de iniciativas pedagógicas 
pensadas sistematicamente e de forma eficiente, pois "todas compartilham do desejo de extrair o potencial educacional de tais ferramentas e assim estimular aprendizes a participar de modo mais ativo e intenso da construção do seu próprio saber" (XAVIER, 2013 , p. 44). Assim, as tecnologias poderão favorecer o desenvolvimento de práticas mais dinâmicas e ressignificar os papéis do professor e do aluno nos processos de ensino e de aprendizagem. A participação mais efetiva dos alunos pode favorecer o desenvolvimento da autonomia e a assunção de uma posição mais crítica nas situações de aprendizagem e na vida social.

Para que o processo de ensino e de aprendizagem seja perspectivado com base nos resultados de pesquisas sobre o uso de tecnologias, Xavier (2013) elenca alguns pontos a serem considerados, a seguir: a) integração entre a teoria e a prática; b) elaboração de atividades que explorem o potencial tecnológico dos artefatos escolhidos pelo professor; c) convergência de diferentes semioses: texto, imagem, sonoridade, etc.; d) flexibilidade para reagir aos imprevistos inesperados no planejamento diante de dificuldades do aluno; e) correlação entre a aprendizagem presencial e a móvel a fim de estabelecer possibilidades de aprendizagem mesmo fora do espaço escolar.

Ao se referirem a esses usos sociais da leitura e da escrita nos espaços virtuais, pesquisadores recorrem ao conceito de letramento digital. De acordo com Ribeiro (2009),

Letramento digital é a porção do letramento que se constitui das habilidades necessárias e desejáveis desenvolvidas em indivíduos ou grupos em direção à ação e à comunicação eficientes em ambientes digitais, sejam eles suportados pelo computador ou por outras tecnologias de mesma natureza. (RIBEIRO, 2009, p. 30).

Essas habilidades podem ser desenvolvidas por meio de uma proposta didática que efetivamente articule escola e sociedade e que considere a natureza das interações que são intermediadas pelas tecnologias. "Para alcançar algum grau de letramento digital, as pessoas precisam aprender várias ações, que vão desde gestos e o uso de periféricos da máquina até a leitura dos gêneros de texto mais sofisticados que são publicados em ambientes on-line e expostos pelo monitor" (RIBEIRO, 2009, p. 33).

No contexto dos letramentos, Dudeney, Hockly e Pegrum (2016) destacam que os letramentos digitais podem ser caracterizados como "habilidades individuais e sociais necessárias para interpretar, administrar, compartilhar e criar sentido eficazmente no âmbito crescente dos canais de comunicação social". Discorrendo sobre os tipos de letramentos, os autores mencionam o letramento em jogos, que consiste na habilidade de navegar e interagir eficientemente nos ambientes de jogos e alcançar objetivos por meio deles. Os jogos também estão articulados ao letramento em multimídia, que se relaciona às habilidades para interpretar e criar textos, utilizando imagens, sons e vídeos. Nesse sentido, os jogos eletrônicos não são contemplados apenas pelo letramento digital, como também por diversos outros tipos de letramentos, o que permite inseri-los no contexto dos multiletramentos, vistas suas especificidades e usos socioculturais.

\section{Novos letramentos, novas leituras}

Ao discorrer sobre os novos letramentos, é necessário explicitar que o conceito de texto aqui adotado está articulado à concepção interacional de linguagem, pois, por meio da leitura, os sujeitos significam e constroem os sentidos dos enunciados em uma 
relação autor-texto-leitor (KOCH; ELIAS, 2010). Em narrativas digitais, por exemplo, esse processo pode ser visualizado ao envolver tanto aspectos linguísticos como não linguísticos em sua estrutura (imagem, música), o que representa uma produção multimodal. Essa integração de traços multimodais na construção linguística e textual traz à tona novas formas de compreensão textual, na medida em que a construção de efeitos de sentido se multiplica do mesmo modo que suas linguagens. Além disso, também se sobreleva um novo tipo de leitor, "trata-se de um tipo especial de leitor, o imersivo, quer dizer, aquele que navega através de fluxos informacionais voláteis, líquidos e híbridos - sonoros, visuais e textuais - que são próprios da hipermídia" (SANTAELLA, 2005, p. 11).

Esse leitor, cada vez mais integrado ao universo do ciberespaço, se depara com textos ${ }^{4}$ cada vez mais multimodais e múltiplos de semioses, exigindo a habilidade de multiletramentos. Rojo (2012) define esses textos como sendo "[...] compostos de muitas linguagens (ou modos, ou semioses) e que exigem capacidades e práticas de compreensão e produção de cada uma delas (multiletramentos) para fazer significar" (ROJO, 2012, p. 19).

Para Dionísio (2011, p. 139),

Se as ações sociais são fenômenos multimodais, consequentemente, os gêneros textuais falados e escritos são também multimodais porque, quando falamos ou escrevemos um texto, estamos usando no mínimo dois modos de representação: palavras e gestos, palavras e entonações, palavras e imagens, palavras e tipografias, palavras e sorrisos, palavras e animações, etc.

Assim, os diferentes recursos como palavras, imagens, som, movimento, cor, enquadramento, hiperlinks são todos aspectos encontrados nos jogos digitais, adicionados a elementos característicos e clássicos desses, como comandos para salvar, se movimentar, se localizar, de menu, play, entre tantos outros que fazem parte da estrutura composicional de jogos eletrônicos, e todos esses aspectos são colocados em prática dia após dia na vida de alunos jogadores, letramento que não é construído da mesma maneira em sujeitos não jogadores. Dessa forma, é possível dizer que há um letramento gâmico? Um letramento que existe em maior ou menor grau em cada sujeito? Zagal (2010 apud SILVEIRA; ROLIM, 2013) estuda esse letramento, chamando-o de ludoliteracy ou ludoletramento. Em sua perspectiva, um sujeito passa a ser letrado em jogos digitais quando, além de ter a capacidade de jogar, compreende os significados desses jogos no contexto da cultura. Em suas palavras, o ludoletramento seria:

[...] a capacidade de explicar, discutir, descrever, enquadrar, situar, interpretar e/ou posicionar os jogos nos seguintes contextos: 1. no contexto da cultura humana (jogos como artefatos culturais); 2. no contexto de outros jogos (comparando-os a outros jogos, gêneros); 3. no contexto da plataforma tecnológica em que são executados; e 4. na desconstrução e compreensão de seus componentes, como eles

\footnotetext{
${ }^{4}$ No contexto das tecnologias, o conceito de texto foi redimensionado. Assim, Bentes, Ramos e Alves Filho (2010) consideram texto como "um lócus de convergências de ações humanas de natureza multissemiótica, interativa e social. Essas definições possibilitam a compreensão do texto como um objeto de estudo que apresenta uma natureza plástica e com fronteiras maleáveis, histórica e socialmente delimitadas" (p. 392).
} 
interagem e como facilitam certas experiências em seus jogadores. (ZAGAL, 2010, grifos do autor, apud SILVEIRA; ROLIM, 2013, p. 4).

Os videogames, como artefatos de plataformas virtuais, apresentam domínios que vão além do semiótico, pois, ao definir suas escolhas dentro do jogo, o sujeito estará participando de práticas de leitura e escrita que existem dentro desse meio, conhecendo uma linguagem que só existe naquele contexto e que é realizado por aquele grupo social de jogadores. Desse modo, como produto presente na cultura popular e que agrega os mais diversos aspectos de diferentes culturas, os videogames possuem a potencialidade de aproximar o ambiente de sala de aula à realidade do aluno, ao conferirem a presença de elementos comuns à cultura jovem, os quais podem ser visualizados no jogo Life is strange, selecionado para análise.

\section{$4 O$ gênero digital game}

Os jogos digitais são considerados textos multimodais na medida em que são caracterizados pela presença de elementos linguísticos e visuais na construção do seu sentido. Santaella (2009) classifica o videogame como um gênero híbrido e multimodal, por apresentar recursos relativos a programação, design, ludologia, narratologia, etc., e que implicam a multiplicidade de linguagens e semioses essenciais à sua formação. Com a popularização dos jogos eletrônicos, novas pesquisas têm encontrado modos diferentes de analisar esse objeto de estudo. A complexidade que decorre da multidisciplinaridade ligada à composição desse objeto resultou na existência de três eixos interdependentes, a julgar como game programming (programação de games), game design (design de games) e game studies (estudos de games). O letramento gâmico pode estar relacionado aos três eixos, visto que, ao considerar a produção desses textos como processo final de desenvolvimento desse letramento, práticas como linguagem específica dos games, apropriação das ferramentas de jogo, como controles do PC ou do console, técnicas de programação, de dinâmicas, além de aspectos relacionados ao impacto cultural desse objeto e, por outro lado, aspectos internos da narrativa (personagens, tempo, espaço, etc.), seriam todos vivenciados pelo sujeito leitor/jogador em menor ou maior grau.

Atualmente, existem diversos tipos de jogos digitais com diferentes objetivos e características, sendo complicado classificá-los sistematicamente, entretanto, pode-se afirmar que sua origem se dá em razão do grande avanço das tecnologias de mesmo caráter a partir do século XX. Pesquisas sobre a evolução desses jogos revelam como eram influenciados diretamente pela realidade de seu contexto de produção. Já hoje, não é necessário que um game tenha um tema específico, incluindo diversas possibilidades de entretenimento, além de não ser necessário estar em um lugar específico para a interação com essas tecnologias, como há alguns anos, quando só jogava quem fosse grande frequentador das lan houses e cybercafés, contrastando com a situação atual, pois se joga em qualquer hora e lugar, em um computador de mesa, notebook, celular, tablet, são inúmeras plataformas que permitem a possibilidade de estar em contato com esses textos. Uma das práticas mais comuns dos jogadores, inclusive, é conseguirem acesso aos jogos por meio de emuladores, sendo possível que, mesmo sem nenhum console original em mãos, eles possam executá-los nos computadores em programas específicos para isso. 
Também são relevantes as relações culturais que emergem desses contextos sociais. Os jogos digitais se enquadram como produções culturais, de acordo com Paula, Hildebrand e Valente (2014), pois se inserem em um campo cultural, envolvendo saberes relacionados ao universo dos games, mas também abordando questões da cultura em geral, o que favorece uma formação mais ampliada, uma vez que, por meio dos jogos, os alunos podem ter acesso a conhecimentos sobre contextos históricos, geográficos e culturais. Essa perspectiva abarca os letramentos múltiplos, tal como concebido por Rojo (2009), ao considerar que, além da questão da multissemiose ou multimodalidade das mídias digitais que lhes deu origem, esse conceito abrange pelo menos duas facetas: "a multiplicidade de práticas de letramento que circulam em diferentes esferas da sociedade e a multiculturalidade, isto é, o fato de que diferentes culturas locais vivem essas práticas de maneira diferente" (ROJO, 2009, p. 108-109). Assim, reconhecer as potencialidades formativas dos jogos digitais poderá propiciar uma exploração das diferentes contribuições desse artefato para a formação de leitores proficientes.

\section{Jogos em sala de aula}

Refletindo-se, novamente, sobre a concepção sociointeracional da linguagem, em que, de acordo com Koch (2006, p.), linguagem é "lugar de 'inter-ação' entre sujeitos sociais, isto é, de sujeitos ativos, empenhados em uma atividade sociocomunicativa", é possível relacionar a utilização dos jogos eletrônicos, textos interativos, em um intenso processo de múltiplas linguagens. Nesses textos, o leitor passa a ser também coautor da narrativa, pois nada acontece até que ele faça uma opção, dessa forma, os jogos eletrônicos são textos sociointeracionais, pois o jogador interage com outros jogadores e também com personagens, ambientes e elementos dos games.

A experiência de jogar permite que o sujeito se aproxime de situações de aprendizagem significativas, que permitem uma análise contextualizada de questões linguísticas, semióticas e discursivas, bem como questões ligadas à arte e à literatura. Dessa forma, entende-se como esse objeto pode ser uma fonte criativa e metodológica de ensino nas aulas de Língua Portuguesa, ou em qualquer outra área. A fim de elencar algumas práticas possíveis em sala de aula com a utilização dos jogos digitais, recorrese a Aguiar (2017), Silveira e Rolim (2013) e Moreira e Cruz (2009). Cada pesquisa visa apresentar habilidades distintas de aprendizado. Aguiar (2017), por meio do quadro a seguir, seleciona habilidades linguísticas e textuais que podem ser encontradas em games e direcionadas às aulas de Língua Portuguesa: 
Quadro 1 - Quadro com as habilidades

\begin{tabular}{|l|l|}
\hline \multicolumn{1}{|c|}{ Etapas } & \multicolumn{1}{|c|}{ Níveis } \\
\hline Prática situada & $\begin{array}{l}\text { Experimentar o conhecido: do que já é conhecido pelos alunos, } \\
\text { identificar vivências, motivações, interesses pessoais em relação } \\
\text { aos jogos digitais e à cultura gamer. } \\
\text { Experimentar o novo: apresentar novas perspectivas e informações } \\
\text { (textos, imagens, vídeos etc.) para promover experiências } \\
\text { inovadoras, entre as quais, destacamos situações reais de } \\
\text { interlocução motivadas pelos gêneros textuais da cultura gamer. }\end{array}$ \\
\hline Instrução explícita & $\begin{array}{l}\text { Conceituar por nomeação: nomear os gêneros textuais presentes } \\
\text { no game Life is strange; elencar características do game e termos } \\
\text { recorrentes. } \\
\text { Conceituar por teoria: apresentar conceitos teóricos acerca dos } \\
\text { elementos que compõem o jogo e os gêneros textuais a ele } \\
\text { relacionados, de modo a promover uma compreensão mais ampla, } \\
\text { tanto do jogo quanto dos gêneros. }\end{array}$ \\
\hline $\begin{array}{l}\text { Enquadisar funcionalmente: refletir sobre o objeto de estudo (Para } \\
\text { crítico }\end{array}$ & $\begin{array}{l}\text { que serve determinado gênero textual? Qual é seu propósito } \\
\text { comunicativo? A que comunidade discursiva é dirigido? Qual é a } \\
\text { situação de produção? Que sentidos são produzidos pela estrutura } \\
\text { textual e pela seleção lexical?). } \\
\text { Analisar criticamente: examinar de forma reflexiva, entre outros } \\
\text { aspectos, as intenções presentes em um texto; seus significados; } \\
\text { relações de poder que estabelece, consequências individuais, } \\
\text { ambientais e sociais. }\end{array}$ \\
\hline Aplicação & $\begin{array}{l}\text { Aplicar apropriadamente: realizar ações linguísticas que ocorrem } \\
\text { no contexto social mais amplo; promover a compreensão, por } \\
\text { parte do aluno, da realidade e do objeto de estudo. } \\
\text { Aplicar criativamente: elaborar resenhas, detonados, tutoriais, } \\
\text { vídeos, posts, entre outros gêneros; publicação das produções orais } \\
\text { e escritas em canais como Youtube, Facebook, Steam, Snapchat } \\
\text { ou por meio de blogs e fanzines elaborados colaborativamente } \\
\text { pelos próprios alunos. }\end{array}$ \\
\hline Konte: adaptado de Kalantzis e Cope (2006) \\
\hline Kalanta
\end{tabular}

Fonte: Retirado de Kalantzis e Cope (2016 apud AGUIAR, 2017).

Já Moreira e Cruz (2009) chamam a atenção para os aspectos narrativos desses textos digitais que podem ser levados para a sala de aula, como mostrado em sua metodologia a seguir:

Após o experimento em grupo feito em um laboratório de informática na sede do colégio, o primeiro passo foi reconhecer o espaço, o tempo e os personagens dos games praticados pelos alunos. O que chamamos e explicamos a eles é que se tratava de leitura de imagens e quanto isso é importante na cultura contemporânea. O primeiro exercício foi o de descrição dos games. Identificar os elementos narrativos e o enredo posto ou possível. Na sequência, os alunos iniciaram a elaboração de decupagem do game para identificar características dos personagens. Com essas informações, solicitamos que eles criassem personagens e ou narradores das narrativas a serem desenvolvidas posteriormente. Cada jogador, agora também um leitor e um narrador, produziu um texto que variou entre uma e dez páginas. (MOREIRA; CRUZ, 2009, p. 182),

Por fim, Silveira e Rolim (2013), por meio do ludoletramento, apresentam habilidades de letramento que são acionadas pelos leitores/jogadores, como é possível visualizar no quadro a seguir:

Quadro 2 - Habilidades relacionadas ao ludoletramento 


\begin{tabular}{|c|c|}
\hline $\begin{array}{l}\text { Contextos de uso de } \\
\text { letramento, descritos por } \\
\text { Zagal (2010, p. 24) }\end{array}$ & $\begin{array}{l}\text { Recursos ou ações utilizados pelos sujeitos da pesquisa, } \\
\text { durante a partida do jogo e/ou sua análise. }\end{array}$ \\
\hline $\begin{array}{l}\text { 1. contexto da cultura } \\
\text { humana (jogos como } \\
\text { artefatos culturais) }\end{array}$ & $\begin{array}{l}\text { Estabeleceram relação do game com outras mídias ou outras } \\
\text { obras, como a adaptação do videogame para o filme O Inferno } \\
\text { de Dante, em animé, em 2010; A Divina Comédia e sua } \\
\text { concepção de inferno, os pecados capitais e suas representações } \\
\text { na bíblia, no discurso religioso. }\end{array}$ \\
\hline $\begin{array}{l}\text { 2. contexto de outros jogos } \\
\text { (comparando-os a outros } \\
\text { jogos, gêneros) }\end{array}$ & $\begin{array}{l}\text { Reconheceram elementos da estrutura do gênero videogame } \\
\text { presentes em outros jogos, como as telas de abertura; de } \\
\text { bonificação; de pontuação; de melhorias; as armas; a barra de } \\
\text { vida. }\end{array}$ \\
\hline $\begin{array}{l}\text { 3. contexto da plataforma } \\
\text { tecnológica em que são } \\
\text { executados }\end{array}$ & $\begin{array}{l}\text { Seguiram instruções dadas, quando apertaram o joypad, } \\
\text { reconhecendo os códigos } \square \circ \mathbf{X} \text {. } \\
\text { Acessaram as bonificações disponiveis nas telas para aumento } \\
\text { de nivel. } \\
\text { Salvaram o jogo. Resolveram os puzzles. Desceram a arena do } \\
\text { jogo. Abriram e fecharam portas. Utilizaram alavancas. }\end{array}$ \\
\hline $\begin{array}{l}\text { 4. desconstrução e } \\
\text { compreensão de seus } \\
\text { componentes. }\end{array}$ & $\begin{array}{l}\text { Realizaram tarefas para alcançar outra, como a aquisição de } \\
\text { reliquias que permitiram upgrades. } \\
\text { Controlaram o avatar, que abarcou ações como lutar, usar as } \\
\text { armas, correr, saltar, caminhar nas paredes, derrotar os } \\
\text { inimigos. }\end{array}$ \\
\hline
\end{tabular}

Essas metodologias foram selecionadas com uma justificativa: a análise que será feita a seguir do jogo Life is strange contemplará vários níveis de habilidades e competências, a fim de comprovar a variedade de possibilidades pedagógicas relacionadas à utilização dos jogos digitais em sala de aula. Entretanto, considera-se que todos esses conhecimentos estão correlacionados às práticas dos multiletramentos.

\subsection{Análise do jogo Life is strange}

O jogo selecionado para análise, Life is strange, participa de uma categoria chamada de adventures, na qual as narrativas demandam ações do jogador para decidir qual caminho percorrer, por meio de comandos de textos, como "ler o cartaz", "abrir a porta", "tirar foto", etc. Em resposta a esses comandos, o jogo segue sua narrativa e se desenvolve, podendo traçar desfechos alternativos. Em uma linguagem técnica de programação, fala-se, conforme Ferreira (2008), que:

A interatividade presente nos adventures é baseada em um sistema de entrada e saída de dados, ou seja, ao receber um comando por parte do jogador, o game (software) busca em seu código de programação a resposta apropriada para aquele comando. [...] No contexto dos games, esta lógica funcionaria da seguinte forma: dada uma situação, se a resposta for $\mathrm{A}$, tome o caminho $\mathrm{X}$; se $\mathrm{B}$, tome o caminho $\mathrm{Y}$, e assim por diante. (FERREIRA, 2008, p. 4).

No caso de Life is strange, o jogo possui dois finais, mas há adventures com um número relativamente grande de conclusões. O interessante nessa proposta em se trabalhar com esses jogos em sala de aula é que o próprio aluno crie outro final se assim desejar, colocando em prática suas habilidades de produção de texto.

Além disso, Life is strange também se encaixa na categoria de serious fun, ou seja, categoria de jogos que podem causar efeitos prolongados sobre o jogador fora do ambiente de simulação, a partir da participação de fóruns, eventos, gameplays, etc. Os 
enredos dos jogos dessa categoria promovem emoções e reflexões em seus usuários, partindo das decisões e escolhas que estes fazem durante o percurso da narrativa. Portanto, é possível que cada jogador crie uma linha de narrativa sobre um mesmo jogo baseado em seus gostos e experiências pessoais.

Life is strange é um jogo desenvolvido pelo estúdio francês DONTNOD e publicado pela SQUARE-ENIX em 2015, composto por cinco episódios: "Chrysalis", "Out of Time", "Chaos Theory", "Dark Room" e "Polarized". Ele está disponível digitalmente para as plataformas PS4, PS3, XBOX ONE, XBOX 360 e na plataforma Steam para download no computador. O game apresenta um mix de drama, aventura, romance e é composto por cutscenes e câmera em terceira pessoa. A história é contada a partir da perspectiva da personagem Maxine Caulfield (Max), estudante da Academia Blackwell, em Arcadia Bay, Oregon. A história da narrativa foca em acompanhar Max em suas aventuras e ajudá-la a descobrir como utilizar o poder de voltar no tempo, o qual ela recebe logo nos primeiros minutos do primeiro episódio, "Chrysalis".

Para a análise empreendida nesta pesquisa, há duas considerações que são necessárias: a) a análise será feita utilizando recortes dos dois primeiros episódios ("Chrysalis" e "Out of Time"), o que se justifica pelo extenso conteúdo que o game proporciona e que foge ao objetivo do trabalho em questão; b) a viagem no tempo será apenas mais uma característica da narrativa e não será tomada como aspecto fundamental no processo de letramento gâmico. Isso será explicado do seguinte modo: essa "ferramenta" será extremamente importante para o jogador, pois, quando se faz uma escolha equivocada, que gere arrependimento ou consequências negativas à personagem, o jogador pode alterar sua escolha voltando no tempo, mas essa função não é determinante para que o jogador possua ou não escolhas durante a narrativa, pois há vários outros adventures que não possuem tal característica e conseguem manter a variedade de desfechos. Portanto, o jogador cria diferentes linhas temporais por meio das escolhas que se abrem ou se fecham para a construção do enredo, o que é constatado pela frase de introdução do game: "Life is strange é um jogo que permite ao jogador influenciar a história. Todas as suas ações e decisões terão um impacto sobre o passado, o presente e o futuro. Escolha com sabedoria...".

Antes de realizar a análise, é necessário um resumo sobre os dois episódios utilizados para o recorte de cenas. "Chrysalis", o primeiro episódio, se inicia com Max em meio a uma tempestade, e o jogador precisa levar a personagem até o farol onde ela estaria segura, entretanto, ao chegar lá, Max se depara com um imenso tornado prestes a destruir Arcadia Bay. Posteriormente, Max e o jogador que a controla tomam conhecimento de que o tornado é resultado de inúmeras situações em que ela manipulou o tempo. Para os conhecedores de ficção científica, esse tipo de situação é frequentemente retratado como efeito borboleta. Esse efeito começa a ser gerado a partir do momento em que a personagem principal volta no tempo para salvar a vida de sua amiga de infância Chloe, logo no início da narrativa. Durante todo esse episódio, Max e Chloe, juntas, seguem na missão de desvendar os mistérios desse poder.

Já no começo do segundo episódio, "Out of Time", Max acorda após uma longa noite estudando todas as teorias científicas sobre o efeito borboleta e sobre seu poder de voltar no tempo, entretanto, ela não encontra nenhuma razão para ter adquirido essa habilidade. Dessa forma, a trama desse episódio segue por outro caminho. Kate, outra aluna da Academia Blackwell, sofre bullying de várias colegas tidas como populares e de líderes de um famoso clube onde ocorrem festas e encontros desses jovens. Kate foi convidada a participar de uma dessas festas, mas, após seu fim, em que ela não se lembra de nada, é compartilhado um vídeo na internet a difamando. Max e o 
leitor/jogador precisam juntar provas que justifiquem a inocência de Kate. Na análise a seguir, é possível visualizar como o jogador precisa ser extremamente cauteloso e prestar atenção nas pistas deixadas durante a narrativa, para que não faça uma escolha equivocada que acabe afetando a vida dos personagens de forma negativa.

Nas quatro primeiras figuras, serão analisados aspectos relativos ao design dos games em geral:

Figura 1 - Menus de opções

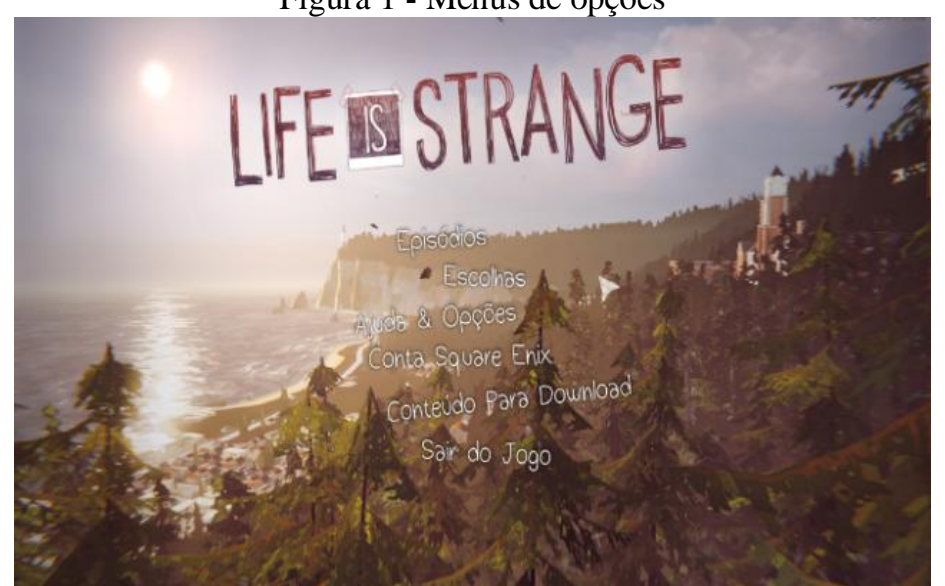

Fonte: Captura de tela de Life is strange no sistema operacional Windows 10.

Figura 2 - Aviso dos desenvolvedores do jogo

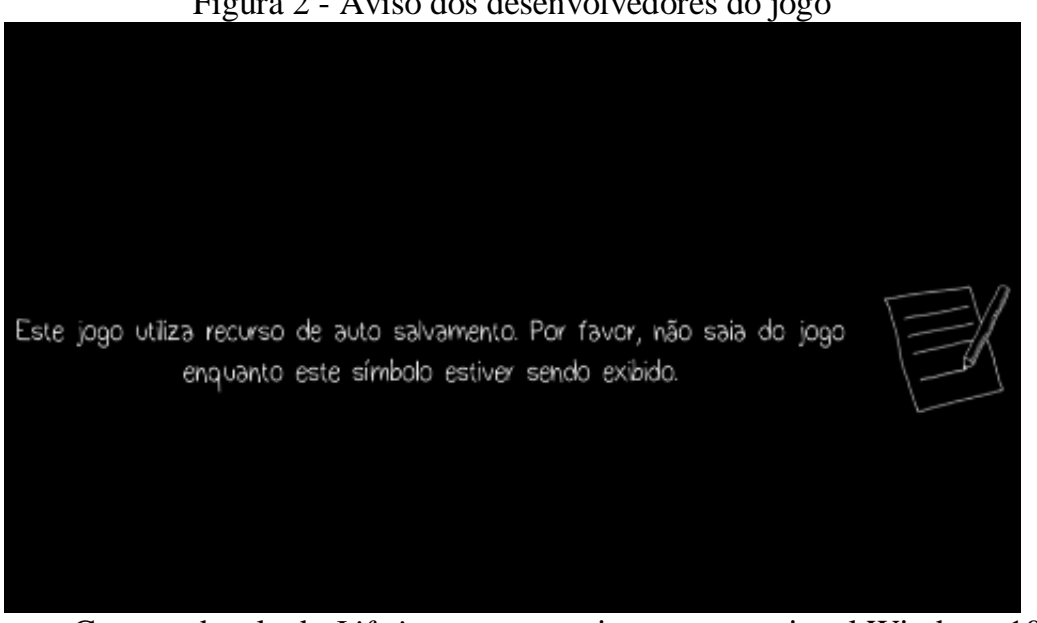

Fonte: Captura de tela de Life is strange no sistema operacional Windows 10.

Figura 3 - Diário de Max/ Objetivos concluídos ou bloqueados (Episódio 2)

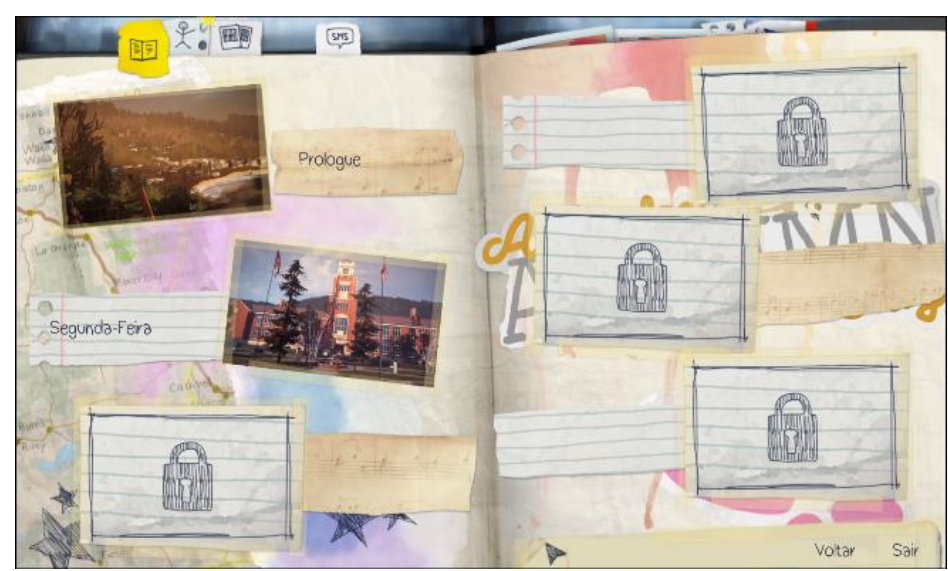

Fonte: Captura de tela de Life is strange no sistema operacional Windows 10. 
Figura 4 - Diário de Max/ Personagens conhecidos ou bloqueados (Episódio 2)

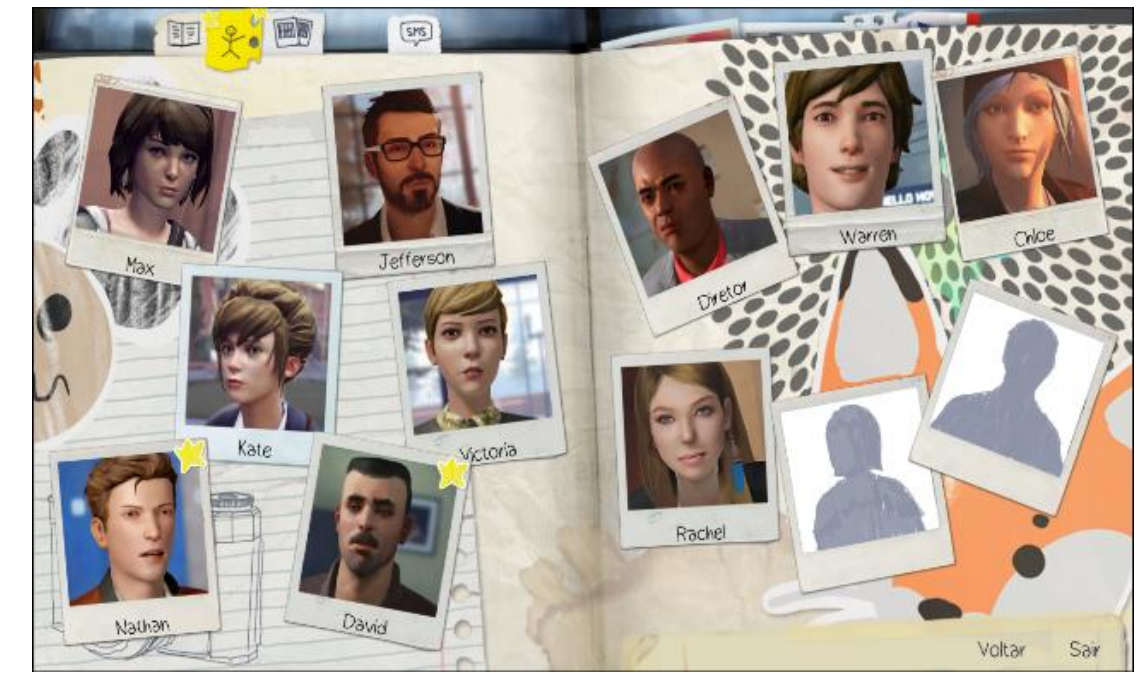

Fonte: Captura de tela de Life is strange no sistema operacional Windows 10.

Na Fig. 1, vê-se o menu do jogo Life is strange, como é possível visualizar pelo letreiro. Dentro desse menu, há opções como "Episódios", "Escolhas", "Ajuda e Opções", "Conta Square Nix", "Conteúdo para Download" e "Sair do Jogo". Essas opções podem variar de um jogo para outro, mas, normalmente, elas possuem as mesmas funções. Em "Episódios", escolhe-se em qual deles o jogador quer navegar, entretanto, diferentemente do primeiro, os outros quatro ficam bloqueados até que o jogador finalize um por um. Após completar todos, o jogador pode escolher qualquer um que desejar, sem ter que passar pelo mesmo processo. Em "Escolhas", ao mesmo passo que a opção anterior, são escolhidas cenas específicas dentro de cada episódio, nas quais ocorre o save do jogo. "Ajuda e Opções" é indicado para auxiliar nas dúvidas dos jogadores em como usar os controles ou, até mesmo, caso queiram alterar os controles previamente instaurados, além da opção de alteração das definições de vídeo e som. "Conta Square Nix" está veiculado à conta utilizada para instalar e acessar o jogo na plataforma original, assim como " Conteúdo para Download" permite acessar outros recursos que são disponibilizados pela plataforma. E, por fim, "Sair do Jogo", como o próprio nome diz, é utilizado para se retirar do game. Compreender as opções e seus usos integram habilidades relacionadas aos letramentos digitais e, de modo mais específico, ao letramento gâmico.

Na Fig. 2, visualizam-se os desenvolvedores do jogo chamando a atenção para o recurso de autossalvamento. Diferentemente de outros jogos, o jogador não precisa passar por checkpoints (pontos para salvar o progresso), pois o autossalvamento é realizado quando há grandes alterações e progressões na narrativa. É aconselhado não fechar o game enquanto o símbolo estiver na tela, pois o jogador perderá seu progresso de jogo.

Nas Fig. 3 e 4, aparecem conteúdos que devem ser desbloqueados pelo jogador ao longo da história. Esse bloqueio é simbolizado pelos personagens em anonimato e pelos cadeados, respectivamente. Eles se referem à necessidade de Max conhecer os personagens e interagir com eles, para só então aparecerem no seu diário; e, depois de concluir certos objetivos, à disponibilização de outros. Todas as características discutidas até aqui são clássicas dentro dos jogos digitais e estão relacionadas ao game design, sendo fundamentais para o letramento gâmico. 
A seguir, serão analisados os textos e gêneros textuais coexistentes nos jogos e em situações da vida real:

Figura 5 - Diário de Max/ Segundo dia (Episódio 2)

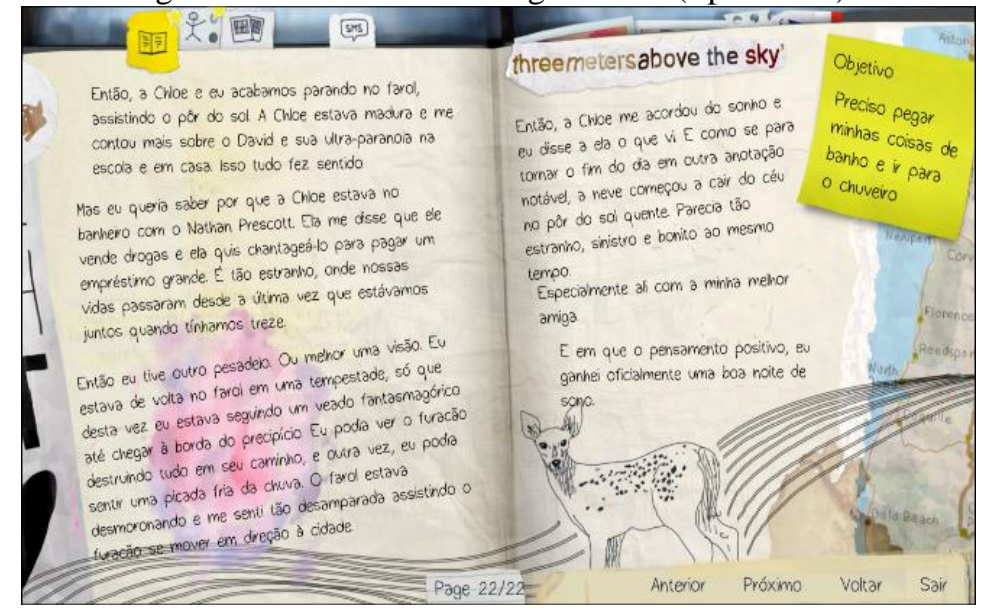

Fonte: Captura de tela de Life is strange no sistema operacional Windows 10.

Figura 6 - Celular de Max (Episódio 2)

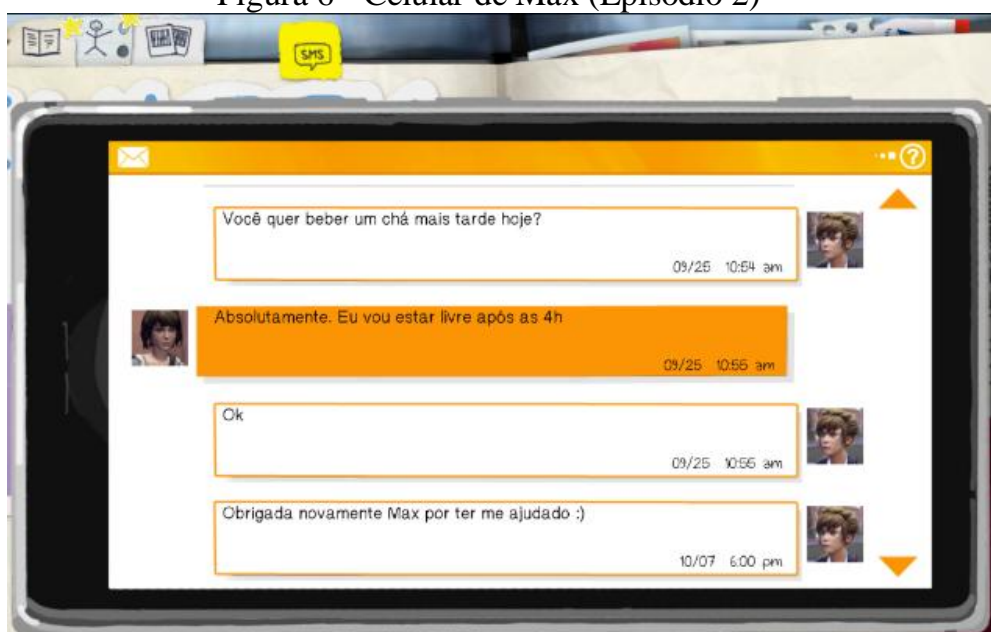

Fonte: Captura de tela de Life is strange no sistema operacional Windows 10.

Figura 7 - Caixa de e-mail de Max (Episódio 2)

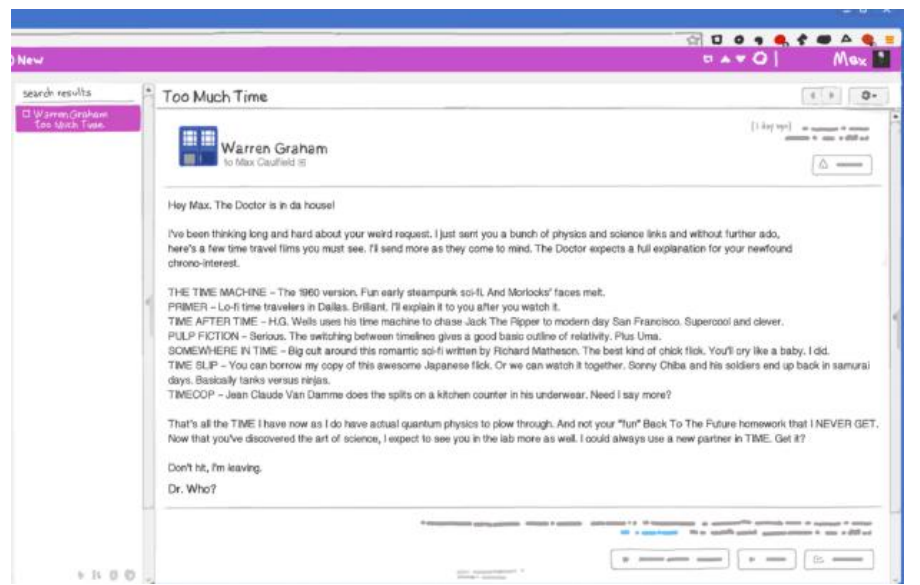

Fonte: Captura de tela de Life is strange no sistema operacional Windows 10. 
Na Fig. 5, é apresentado o diário de Max. Ele aparece desde os primeiros minutos do primeiro episódio e acompanha, dia após dia, a progressão que é realizada na narrativa. As diferentes escolhas do jogador irão influenciar a forma como o diário será escrito, bem como o seu conteúdo. No canto superior direito da Fig. 5, nota-se um bilhete que contém o objetivo de Max para aquele momento, objetivo que precisa ser alcançado pelo jogador para a história continuar seu caminho.

Nas Fig. 6 e 7, estão as mensagens de textos trocadas com Kate e um e-mail recebido por Warren (outro personagem, amigo de Max), respectivamente. Inclusive, essas mensagens de texto demonstram como a aproximação dessas duas personagens é essencial para a narrativa desse episódio, como dito anteriormente.

Dessa forma, nesta análise, são observados quatro gêneros textuais distintos: diário, bilhete, mensagem de texto e e-mail. Dentro das aulas de Língua Portuguesa, no que se refere às habilidades de leitura e produção de textos, é interessante considerar a abordagem utilizada em jogos como esse para se repensar as práticas de desenvolvimento em sala de aula. Portanto, além de o próprio jogo se caracterizar como um gênero, ele ainda pode apresentar em sua constituição outros gêneros, o que é denominado por Marcuschi (2002) de intergenericidade.

Nesse contexto dos jogos, é possível explorar uma dimensão interacional da leitura. Para Dell'Isola (1996, p. 168), “o texto verbal ou não verbal é enunciação projetada, continuada ad infinitum e perpetuada pelo leitor, um exercendo influência sobre o outro". Nessa relação entre página impressa, imagem (acústica ou visual) e o sujeitoleitor, são construídos os sentidos dentro da multiplicidade de possibilidades que a linguagem permite.

Assim, segundo Cajueiro (2014), os jogos apresentam como características não apenas as dimensões linguísticas, mas a interatividade e a multimodalidade, o que resulta em mudanças de fatores de ordem funcional, formal e estrutural, que são, consequentemente, responsáveis por transformação de gêneros, como exemplo, uma narrativa impressa em uma narrativa digital. Para o autor, os jogos digitais se inscrevem em uma perspectiva da interação situacional, que insere a possibilidade de agir e interferir no ambiente interativo proposto. Assim, considerando a questão dos gêneros, o autor destaca o estilo, o tema e a forma dos jogos digitais. Para ele, "o estilo de um jogo digital pressupõe as escolhas tomadas no modo de representação de seu mundo diegético e em escolhas tomadas na representação das interfaces, como tipografia e uso de ícones" (CAJUEIRO, 2014, p. 72). Esse mundo diegético, ou seja, ficcional, constrói a realidade da própria narrativa e deve ser tomado como referência para a produção de sentidos. Em relação ao tema, o autor pontua que os temas dos jogos digitais carregam consigo uma porção de suposições por parte dos jogadores, em relação às características narrativas, de interface, sistema de pontuação, estilo de representação do mundo diegético (ficcional) e composição de jogadores. E esse tipo de acordo não verbal sobre o que é esperado de um texto é exatamente o que propicia a identificação dos jogos como um gênero. Ainda segundo o autor, no que diz respeito à forma, é necessário considerar várias questões, tais como suporte, linguagem de programação, regras, interatividade, ambiente discursivo (condições de produção do jogo, de construção dos discursos, de interpretação), pois cada tipo de jogo pode emanar formatos diferentes. Analisar essas questões poderá favorecer a compreensão do funcionamento dos jogos e, por consequência, contribuir para a ampliação de habilidades relacionadas aos multiletramentos.

A seguir, serão analisados aspectos relativos a jogabilidade, interação e controles do jogador em Life is strange: 
Figura 8 - Quarto de Max. O jogador acaba de optar por regar a planta (Episódio 2)

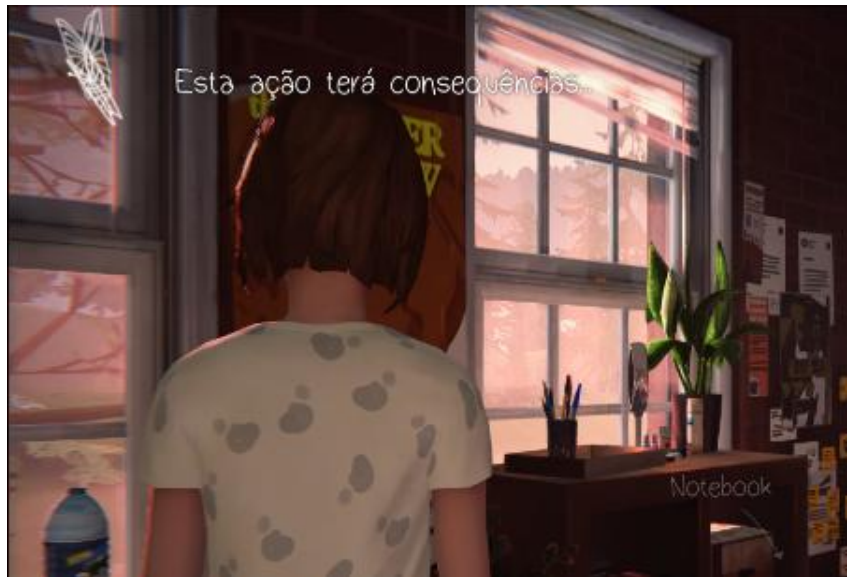

Fonte: Captura de tela de Life is strange no sistema operacional Windows 10.

Figura 9 - Quarto de Max. O jogador só pode sair do quarto após concluir o objetivo (Episódio 2)

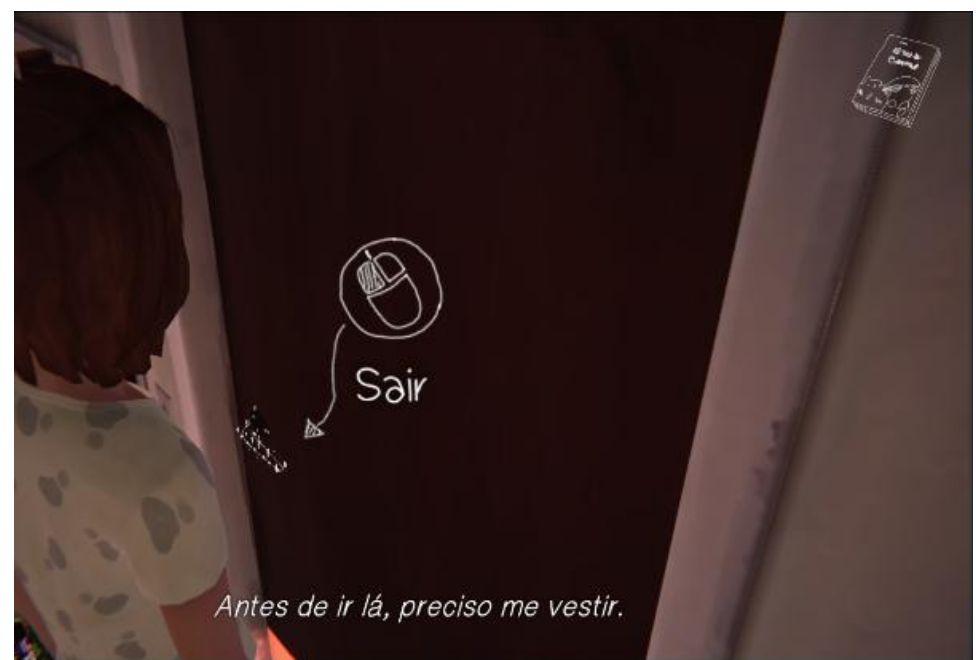

Fonte: Captura de tela de Life is strange no sistema operacional Windows 10.

Figura 10 - Quarto de Kate. Max e Kate conversam sobre a festa no clube Vortex (Episódio 2)

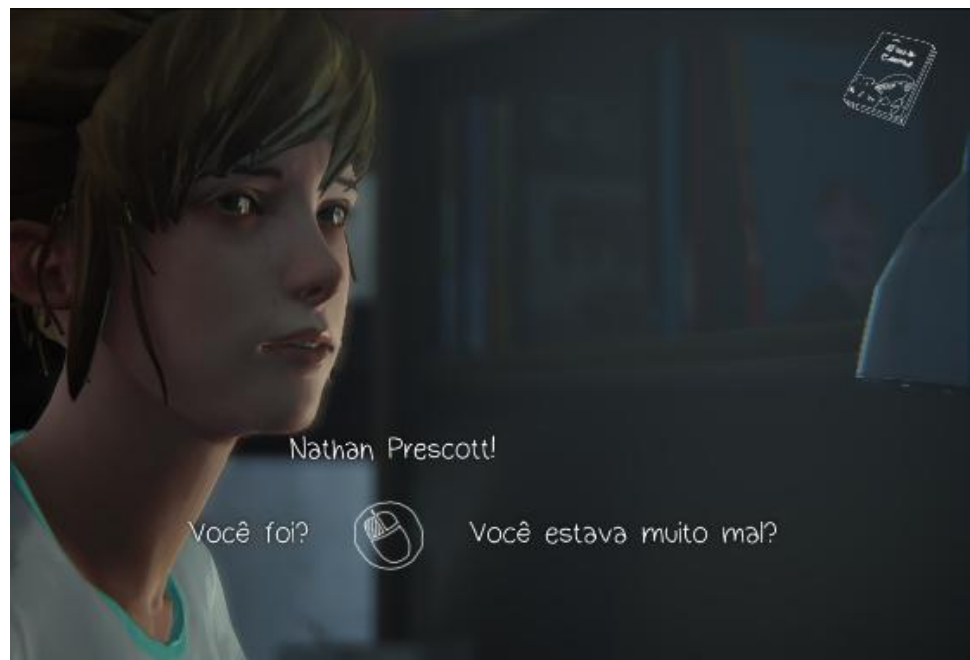

Fonte: Captura de tela de Life is strange no sistema operacional Windows 10. 
Figura 11 - Quarto de Kate. Kate pergunta à Max qual decisão ela deve tomar (Episódio 2)

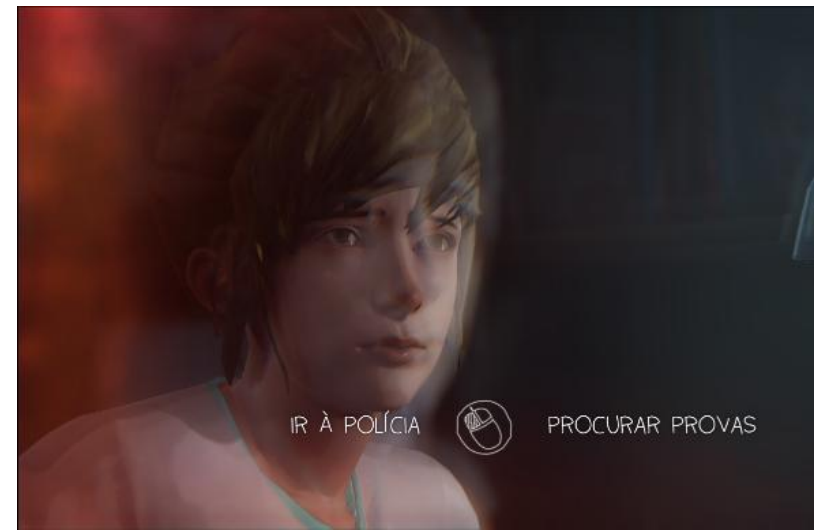

Fonte: Captura de tela de Life is strange no sistema operacional Windows 10.

Na Fig. 8, o jogador acaba de realizar uma ação que irá provocar consequências significativas no rumo da história. Dessa forma, instantaneamente, aparece o símbolo de uma borboleta no canto superior da tela, sendo que esse símbolo é utilizado, dentro do game, sempre que for preciso indicar o impacto da escolha do jogador naquele momento. Na Fig. 9, Max tem como objetivo devolver um livro a Kate, entretanto, o game só permite que o jogador saia do quarto assim que Max trocar de roupa. Essa cena foi utilizada para ilustrar como há momentos em que a narrativa encontra meios para determinar as escolhas do jogador em uma direção necessária.

Nas Fig. 10 e 11, o jogador precisa fazer escolhas em relação ao diálogo que está em desenvolvimento. No primeiro caso, mesmo que as opções possam gerar diferentes reações nas personagens, não são urgentes a ponto de deslocarem a narrativa, diferentemente do segundo caso, na Fig. 11, em que há o congelamento da cena, além da presença de flashes vermelhos e um som de suspense, de forma a demonstrar o nível de seriedade daquelas duas escolhas, ou seja, o jogador precisa pensar bem antes de tomar qualquer opção.

A seguir, diante das Fig. 12 e 13, além de ser possível visualizar as possibilidades de interação ao redor da personagem Max (diário, câmera, etc.), percebe-se o ambiente acadêmico no qual ela e a narrativa estão inseridas. À sua frente, encontra-se o professor Jeffersons aplicando uma aula expositiva sobre fotografia, enquanto seus colegas estão espalhados dentro da sala de aula em diferentes carteiras. Nesse ponto, podemos perceber o diálogo entre os espaços compartilhados pelos personagens do game e pelos alunos jogadores, ou seja, ambientes escolares.

Figura 12 - Sala de aula, professor Jeffersons discute sobre fotografia (Episódio 1)

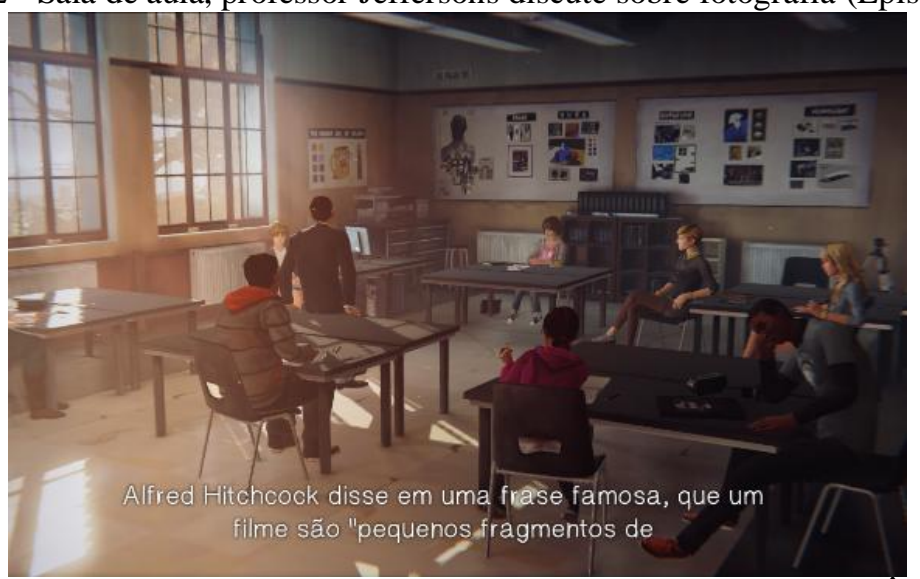

Fonte: Captura de tela de Life is strange no sistema operacional Windows 10 (Ângulo aberto). 
Figura 13 - Sala de aula, professor Jeffersons discute sobre fotografia (Episódio 1)

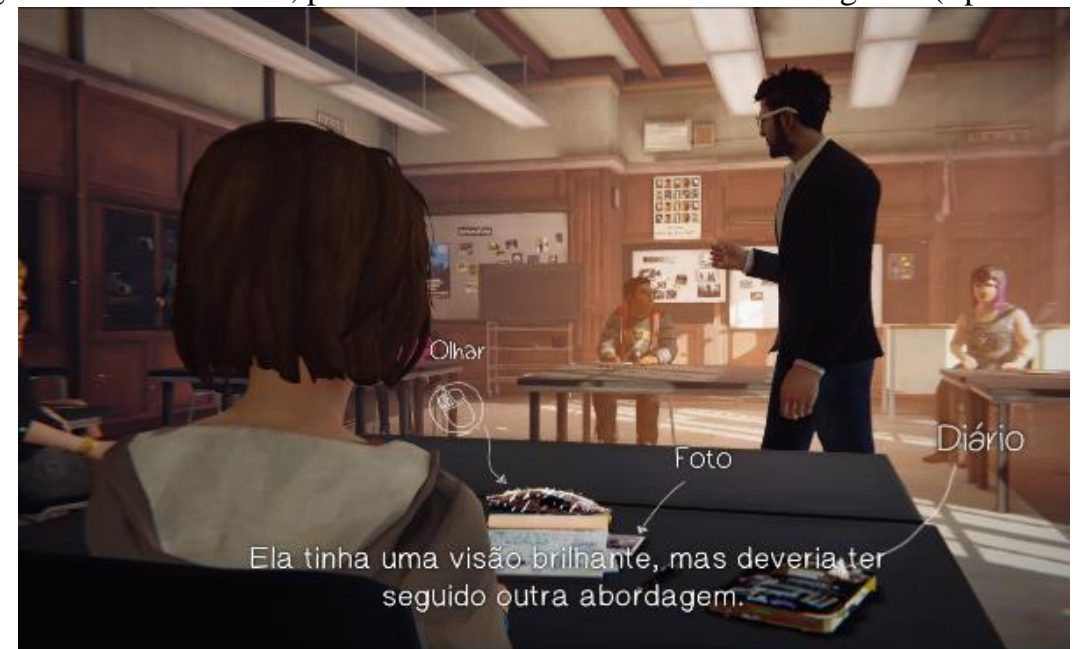

Fonte: Captura de tela de Life is strange no sistema operacional Windows 10 (Ângulo pessoal).

Voltando-se para aspectos relativos à relação entre Max e Kate, são encontradas as seguintes situações:

Figura 14 - Banheiro do dormitório feminino (Episódio 2)

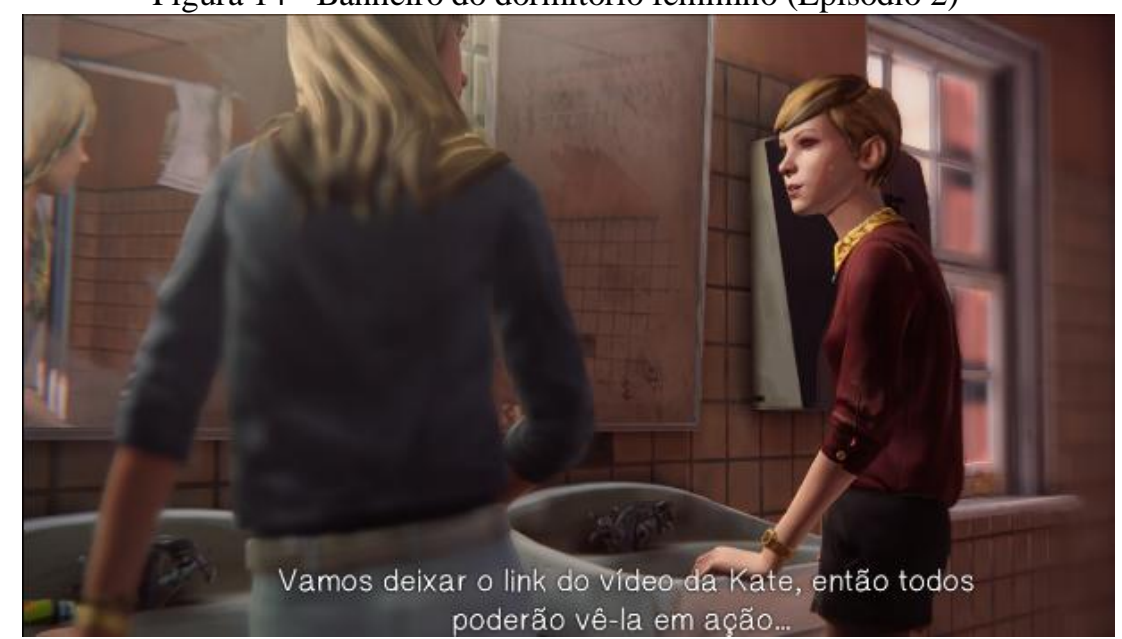

Fonte: Captura de tela de Life is strange no sistema operacional Windows 10.

Figura 15 - Banheiro do dormitório feminino. O jogador tem a opção de apagar o link do vídeo (Episódio 2)

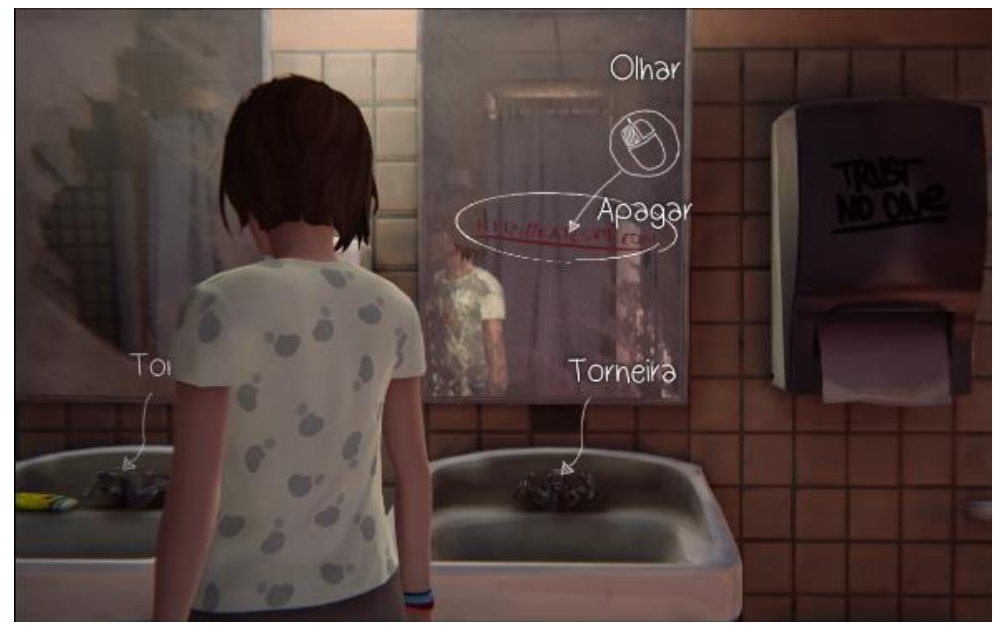

Fonte: Captura de tela de Life is strange no sistema operacional Windows 10. 
Figura 16 - Quarto de Kate. Provérbio de Mateus retirado da Bíblia (Episódio 2)

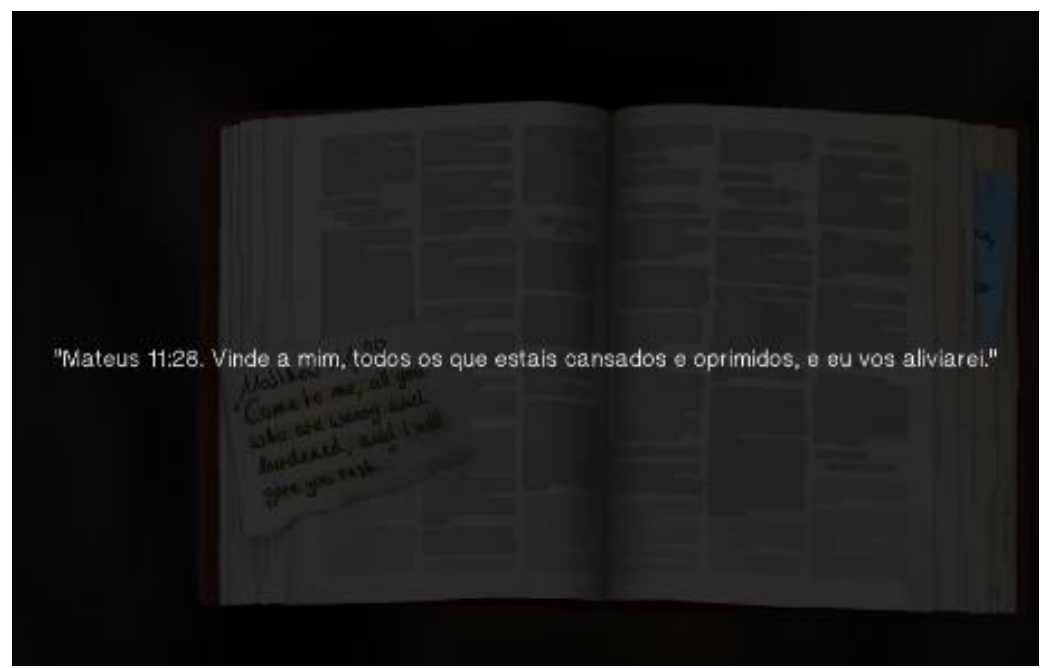

Fonte: Captura de tela de Life is strange no sistema operacional Windows 10.

Figura 17 - Quarto de Kate. Cartão postal enviado pelo pai de Kate (Episódio 2)

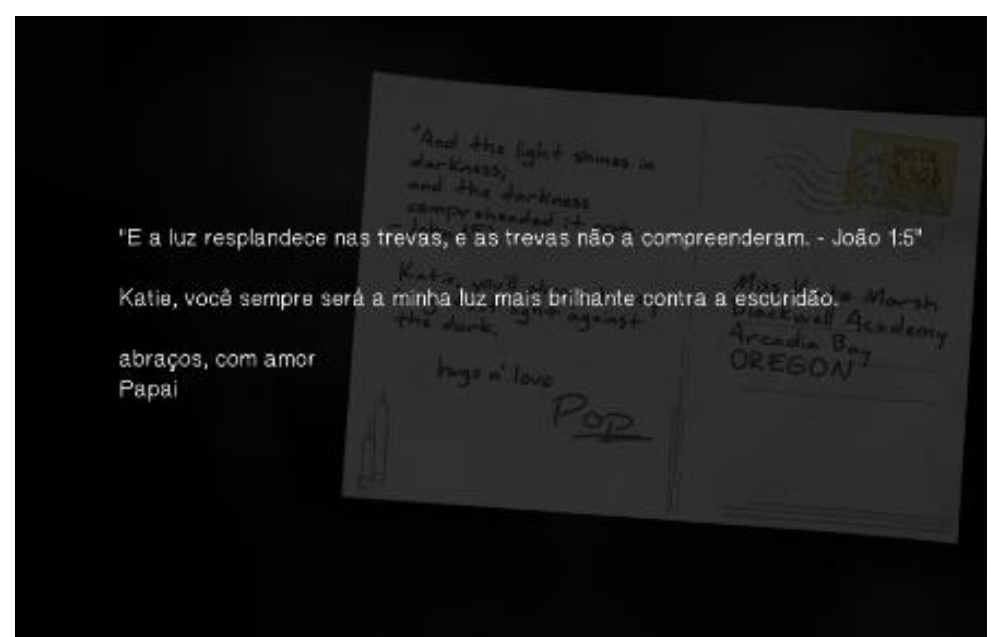

Fonte: Captura de tela de Life is strange no sistema operacional Windows 10.

Victoria, a personagem presente na Fig. 14 com o casaco vinho, é uma das meninas populares que buscam atormentar a vida de Kate e aborrecê-la por meio de insinuações maldosas. Nesse momento específico, ela faz questão de registrar, no espelho, o link de acesso ao vídeo que difama Kate, causador de inúmeros comentários provocativos a seu respeito. Na Fig. 15, o jogador tem a opção de fazer com que Max apague o link do espelho e, assim, instantaneamente, fazer com que apareça o símbolo da borboleta na tela. Essa ação pode ser pequena se comparada a outras na narrativa, mas como a própria personagem principal diz: "Mesmo que eu consiga impedir uma pessoa de assistir ao vídeo, valerá a pena". Essa ação, acrescentada das duas cenas representadas pelas Fig. 16 e 17, são pistas deixadas na narrativa para que o jogador entenda como funciona a personalidade de Kate e seus conflitos internos, bem como sua relação com a família e religião. Essas pistas serão essenciais para o final do episódio "Out of Time", pois, se o jogador selecionar o provérbio errado da Bíblia ou indicar que a mãe é mais próxima de Kate, ao invés de seu pai, a personagem pode acabar sua trajetória ali. 
As duas últimas cenas selecionadas a seguir estão relacionadas ao contexto do jogo Life is strange fora de seu ambiente de simulação, ou seja, a interação existente entre jogadores e jogadores, ou jogadores e mundo. A Fig. 18 representa uma espécie de estatística das ações selecionadas pelos jogadores, desse modo, ao final de cada episódio, é mostrado quais foram as ações geradoras de consequências e quantas pessoas, em porcentagem, tomaram essa ou aquela escolha, agindo como um feedback. Essa estatística é interessante, principalmente, para o fim do primeiro episódio, visto que, ao visualizar esse recurso, o jogador pode sentir a importância de estar atento ao fazer suas escolhas, pois, estas podem ser mais ou menos aceitas pela comunidade gamer. Já a Fig. 19 ilustra a página inicial do website veiculado ao game Life is strange, tendo sua versão em diferentes idiomas (inclusive, o português), além de conter o resumo da história e conteúdos extras.

Figura 18 - Estatística de escolhas ao final do jogo (Episódio 2)

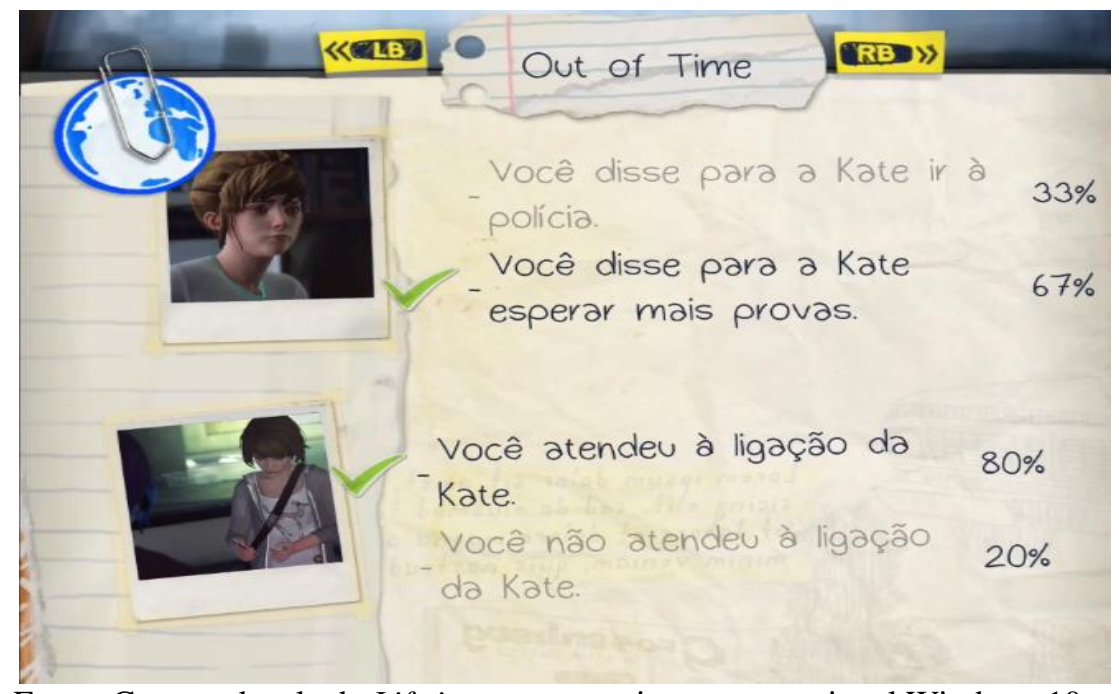

Fonte: Captura de tela de Life is strange no sistema operacional Windows 10.

Figura 19 - Website do jogo Life is strange (Episódio 2)

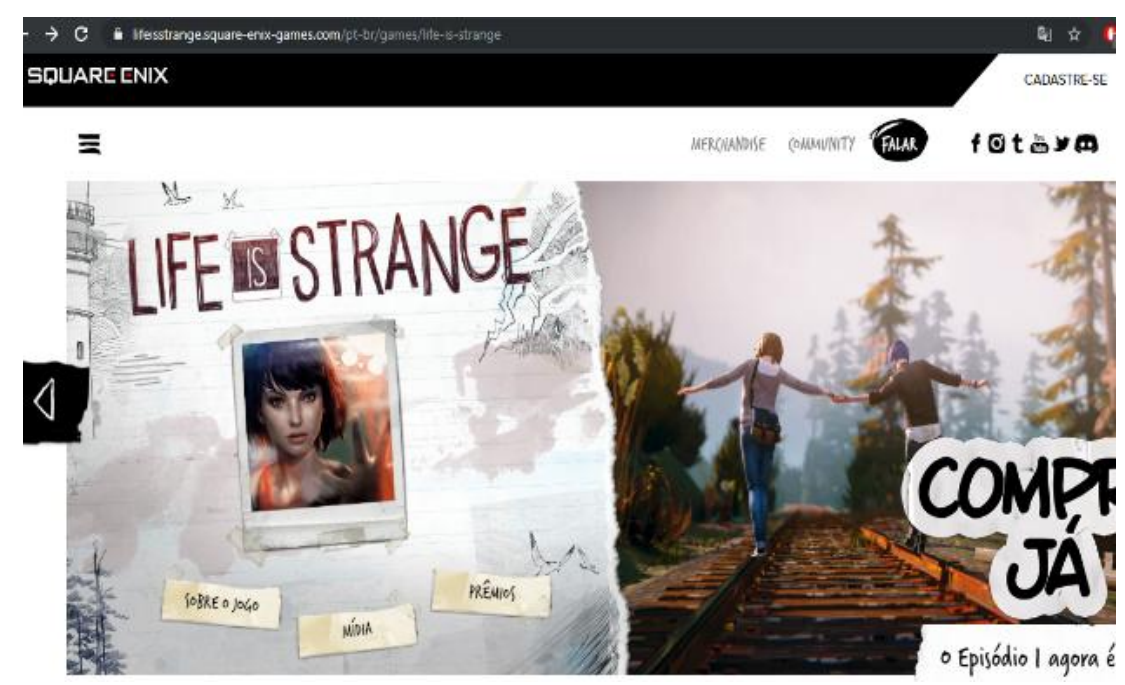

Fonte: Captura de tela de Life is strange no sistema operacional Windows 10.

Portanto, como foi possível observar, o jogador precisa ser um leitor habilidoso em navegação, com graus de letramento gâmico, pois, desse modo, como também é 
realizado com os leitores de hipertextos, o jogador assume os papéis de leitor e de autor, a cada escolha realizada, construindo a narrativa a seu modo. Dessa forma, são listados os aspectos necessários para adquirir esse letramento:

1) Conhecimento em relação aos códigos e à linguagem utilizada nos games;

2) Conhecimento dos elementos visuais e semióticos do game, a fim de criar coesão dentro da narrativa (borboleta - consequências, caderno - autossalvamento, etc.);

3) Conhecimento em relação a aspectos físicos, como habilidades no manuseio dos controles dos consoles ou do PC;

4) Conhecimento dos aspectos composicionais do jogo e da narrativa (cenário, personagens, trilha sonora, design, etc.).

Ao finalizar a análise acerca dos jogos digitais, considera-se que esses jogos, recorrentemente, são construídos por meio de narrativas, possibilitando interação e imaginação nunca antes contempladas pela narrativa linear. A análise aqui empreendida permite comprovar a posição de Murray (2003 apud ALMEIDA; VALENTE, 2012) a qual considera que as narrativas em ambientes virtuais possuem três categorias de estética: a imersão, a agência e a transformação. A imersão representa a experiência de sermos transportados para um lugar simulado, ou seja, ficcional, a qualquer tempo e lugar. A agência está relacionada com a capacidade de realizarmos ações significativas e visualizar os resultados de nossas decisões e escolhas, instantaneamente. Já a transformação nos permite seguir uma jornada própria por meio de infinitas possibilidades dentro da história. Além disso, essas narrativas apresentam aspectos multimodais, por combinarem diferentes linguagens (verbal e não verbal) e recursos multissemióticos, como som, imagem, movimento, etc. A partir da análise realizada, observou-se que os jogos digitais apresentam uma organização complexa e com modos de funcionamento muito diversa, o que exige dos jogadores habilidades específicas para garantir a qualidade das interações.

\section{Considerações finais}

Tendo em vista a importância de se propor reflexões que permeiam as ferramentas tecnológicas e os textos multimodais, que são constituídos por recursos semióticos, tais como escrita, sons, cores, imagens, etc, as narrativas digitais, presentes nos jogos eletrônicos, podem colaborar para esse ensino, em vista do processo de imersão/interação possibilitado por meio dessas atividades. Uma vez que os games fazem parte da cultura popular, essa imersão na narrativa é intensificada pela linguagem semiótica que contribui significativamente para uma aprendizagem contextualizada através da arte, da música e dos textos não verbais. E, desse modo, eles podem desenvolver a percepção do aluno em relação ao fato de que a língua e seus recursos devem ser explorados de modo que o sujeito se faça presente em uma sociedade cada vez mais letrada e permeada pela tecnologia (AGUIAR, 2017).

Espera-se que este trabalho possa ter contribuído para uma discussão acerca dos jogos digitais, visto que se trata de uma possibilidade pedagógica que poderá propiciar contribuições substanciais para a formação de leitores, seja na dimensão linguísticosemiótico-discursiva, seja na dimensão dos multiletramentos, uma vez que ler/jogar demanda saberes diversos sobre o jogo, mas, sobretudo, sobre os usos sociais das diferentes linguagens e de seus efeitos de sentido. 


\section{Referências}

AGUIAR, A. P. S. O jogo digital como recurso para o ensino de língua portuguesa. Percursos Linguísticos, Vitória/ES, v. 7, n. 17, p. 149-159, 2017.

ALMEIDA, Maria Elizabeth Bianconcini de; VALENTE, José Armando. Integração currículo e tecnologias e a produção de narrativas digitais. Currículo Sem Fronteiras, v. 12, n. 3, p. 57-82, 1 jan. 2012. Disponível em: http://www.curriculosemfronteiras.org/index.htm. Acesso em: 16 out. 2019.

BENTES, A. C.; RAMOS, P.; ALVES FILHO, F. Enfrentando desafios no campo de estudos do texto. In: BENTES, A. C.; LEITE, M. Q. (orgs.). Linguística de texto e análise da conversação. Panorama das pesquisas no Brasil. São Paulo: Cortez, 2010.

CAJUEIRO, L. E. C. Gêneros textuais em jogos digitais. 2014. 126 f. Dissertação (Mestrado em Ciências da Linguagem) - Universidade Católica de Pernambuco UNICAP, Recife/PE, 2014.

DELL'ISOLA, R. L. P. A interação sujeito-linguagem em leitura. In: MAGALHÃES, I. (org.). As múltiplas faces da linguagem. Brasília: UNB, 1996. p. 69-75.

DIONISIO, A. P. Multimodalidade discursiva na atividade oral e escrita (atividades). In: MARCUSCHI, L. A.; DIONISIO, A. P. (orgs.). Fala e Escrita. Belo Horizonte: Autêntica, 2005.

DIONÍSIO, A. P. Gêneros textuais e multimodalidade. In: KARWOSKI, A. M.; GAYDECKZA, B.; BRITO, K. (org.). Gêneros textuais: reflexões e ensino. 4. ed. São Paulo: Parábola, 2011. p. 137-152.

DUDENEY, G.; HOCKLY, N. PEDRUM, M. Letramentos digitais. Tradução Marcos Marcionilo. São Paulo: Parábola, 2016.

FERREIRA, E. Games narrativos: dos adventures aos MMORPGs. In: IV SEMINÁRIO DE JOGOS ELETRÔNICOS, COMUNICAÇÃO E EDUCAÇÃO: CONSTRUINDO NOVOS TRILHOS, 4, Salvador/BA, Anais [...]. p. 1-10. 2008.

KOCH, I. G. V.; ELIAS, V. M. Ler e compreender os sentidos do texto. 3. ed. São Paulo: Contexto, 2010.

KOCH, I. G. V. Desvendando os segredos do texto. 5. ed. São Paulo: Cortez, 2006.

MARCUSCHI, L. A. et al. Gêneros textuais: definição e funcionalidade. In: MARCUSCHI, L. A. Gêneros textuais e ensino. v. 20. Rio de Janeiro: Lucerna, 2002.

MOREIRA, C; CRUZ, D. M. As narrativas dos jogos eletrônicos e suas possibilidades educacionais. Teoria e Prática da Educação, Maringá, v. 12, n. 2, p. 179-184, 2009. 
PAUlA, B. H. de; HILDEBRAND, H. R.; VALENTE, J. A. Jogos digitais e o letramento lúdico: a consolidação dos videogames como meio com diferentes possibilidades expressivas. In: SBGAMES 2014 - XIII SIMPÓSIO BRASILEIRO DE JOGOS E ENTRETENIMENTO DIGITAL, 13, 2014, Porto Alegre. SBC Proceedings of SBGames. Porto Alegre/RS: SBC - Proceedings Of Sbgames 2014, Anais [...]. p. 420-428.

PRENSKY, M. Aprendizagem baseada em jogos digitais. São Paulo, SP: SENAC, 2012.

RIBEIRO, A. E. Letramento digital: um tema em gêneros efêmeros. Abralin, v. 8, n. 1, p. 15-38, 2009.

ROJO, R. Letramentos múltiplos, escola e inclusão social. São Paulo: Parábola Editorial, 2009.

ROJO, R. Pedagogia dos Multiletramentos. In: ROJO, R.; MOURA, E. Multiletramentos na escola. São Paulo: Parábola, 2012. p. 11-31.

SANTAELLA, L. Da cultura das mídias à cibercultura: o advento do pós humano. Famecos, Porto Alegre/RS, v. 10, n. 22, p. 23-32, 2003.

SANTAELLA, L. Introdução. In: SANTAELLA, L.; FEITOSA, M. Mapa do Jogo: a diversidade cultural dos games. São Paulo: Cengage Learning, 2009.

SANTAELLA, L. Os espaços líquidos da cibermídia. E-compós, Brasília/DF, v. 2, p. 1$13,2005$.

SILVEIRA, A. P. P. da; ROLIM, A. T. Virando o jogo: o estudo do gênero videogame na escola. Renote: Revista Novas Tecnologias na Educação, Rio Grande do Sul, v. 11, n. 3, p.1-10, 2013.

XAVIER, A. C. Educação, tecnologia e inovação: o desafio da aprendizagem hipertextualizada na escola contemporânea. (Con)textos Linguísticos, Vitória, ES, v. 7, n. 81, p. 42-61, 2013.

Recebido em 09 de fevereiro de 2020

Aceito em 31 de abril de 2020 